\title{
Early Permian transgressive-regressive cycles: Sequence stratigraphic reappraisal of the coal-bearing Barakar Formation, Raniganj Basin, India
}

\author{
Biplab Bhattacharya ${ }^{1, *}$, Joyeeta Bhattacharjee ${ }^{1}$, Sandip Bandyopadhyay ${ }^{2}$, \\ Sudipto BAnerJeE ${ }^{2,3}$ and KAlyAn AdHIKARI ${ }^{3}$ \\ ${ }^{1}$ Department of Earth Sciences, Indian Institute of Technology, Roorkee 247667 , India. \\ ${ }^{2}$ Department of Geology, Hooghly Mohsin College, Chinsurah, Hooghly 712 101, India. \\ ${ }^{3}$ Department of Earth and Environmental Studies, National Institute of Technology, Durgapur 713 209, India. \\ *Corresponding author.e-mail: bbgeofes@iitr.ac.in; bb.geol.dgc@gmail.com
}

MS received 20 January 2017; revised 26 June 2017; accepted 13 July 2017; published online 8 March 2018

The present research is an attempt to assess the Barakar Formation of the Raniganj Gondwana Basin, India, in the frame of fluvio-marine (estuarine) depositional systems using sequence stratigraphic elements. Analysis of predominant facies associations signify deposition in three sub-environments: (i) a river-dominated bay-head delta zone in the inner estuary, with transition from braided fluvial channels (FA-B1) to tide-affected meandering fluvial channels and flood plains (FA-B2) in the basal part of the succession; (ii) a mixed energy central basin zone, which consists of transitional fluvio-tidal channels (FA-B2), tidal flats, associated with tidal channels and bars (FA-B3) in the middle-upper part of the succession; and (iii) a wave-dominated outer estuary (coastal) zone (FA-B4 with FA-B3) in the upper part of the succession. Stacked progradational (P1, P2)-retrogradational (R1, R2) successions attest to one major base level fluctuation, leading to distinct transgressive-regressive ( $\mathrm{T}-\mathrm{R})$ cycles with development of initial falling stage systems tract (FSST), followed by lowstand systems tract (LST) and successive transgressive systems tracts (TST-1 and TST-2). Shift in the depositional regime from regressive to transgressive estuarine system in the early Permian Barakar Formation is attributed to change in accommodation space caused by mutual interactions of (i) base level fluctuations in response to climatic amelioration and (ii) basinal tectonisms (exhumation/sagging) related to post-glacial isostatic adjustments in the riftogenic Gondwana basins.

Keywords. Fluvio-marine; estuary; post-glacial transgression; sequence stratigraphy; Permian; Gondwana.

\section{Introduction}

Isostatic rebound or uplift after deglaciation accompanied by changes in paleoclimatic conditions strongly control the sedimentation pattern in post-glacial environments. Differential vertical movement within the crust caused by post-Talchir glacio-isostatic rebound affected all the Gondwana basins and led to several fault-controlled basins where deposition of the Karharbari Formation (Early Permian) and the overlying coalbearing Barakar Formation (Early Permian) took place under strong climatic and tectonic influences. 
The Permian coal-bearing Barakar Formation of the Lower Gondwana Supergroup was traditionally interpreted as freshwater fluviatile/lacustrine deposits (Casshyap 1970, 1973, 1979; Casshyap and Qidwai 1971; Raja Rao 1987; Casshyap and Tewari 1988, 1991; Veevers and Tewari 1995, and many others). However, in last 20 years or more, re-interpretation of the Barakar sedimentary succession in terms of fluvial-marine interactions has been attempted by several workers (Maiti et al. 1990; Mukhopadhyay 1996; Gupta 1999; Chakraborty et al. 2003; Ghosh et al. 2004; Bhattacharya et al. 2012, 2016). The present paper is an attempt to assess the Barakar Formation of the Raniganj basin in the framework of fluvio-marine interactive depositional systems. A comprehensive depositional model is proposed in the frame of sequence stratigraphic architecture to understand the exact paleogeographic setup of the Raniganj Basin during the early Permian time. The focus of the present study includes: (i) documentation of the facies architecture in Barakar Formation; (ii) reconstruction of the depositional processes in the frame of original paleoenvironmental settings; and (iii) interpretation of the pattern of evolution of the depositional systems from fluvial-dominated to tide-/wave-dominated, through transgressiveregressive cycles. Assessment of the transgressiveregressive cycles in the light of tectonic/basinal changes, fluctuating sea level conditions and progressive climatic shifts will help to reconstruct the paleogeographic-paleoenvironmental parameters in the eastern part of the peninsular India during the late Paleozoic time, which has not been attempted so far for these rocks. A comprehensive picture of fluvial-marine interactions in the frame of post-glacial transgressive setup will provide a complete evolutionary model in the eastern part of Indian Peninsula during the Early Permian period.

\section{Geological background}

Coal-bearing continental sediments of the Gondwana Supergroup rest unconformably on Precambrian country rocks in some isolated fault-bound basins. The Raniganj Basin (figure 1) in eastern peninsular India is known for thick (more than $1000 \mathrm{~m}$ ) succession of coal-bearing Gondwana sediments (table 1). The rocks of the Barakar Formation in the Raniganj Basin are exposed along the north-central part of the basin and conformably overlie the southerly dipping rocks of the Talchir Formation and/or the Karharbari Formation. The Barakar Formation is characterized by thick $(\sim 250$ $\mathrm{m})$ succession of arkosic sandstone, carbonaceous shale and coal. The present study is carried out in the sedimentary successions of the Barakar sediments exposed along the Khudia River, the Barakar River and the exposed sections of the Ramnagar-Chapatoria open pit mines (figure 2). The outcrops show a strike of about $\mathrm{N} 70^{\circ} \mathrm{E}$ with dip of about $15^{\circ}$ towards southwest. Lithology of the study area comprises patchy conglomerate, sandstone-mudstone heterolith, trough crossbedded pebbly sandstone, carbonaceous shale and coal.

\section{Sedimentology}

Bhattacharya et al. (2012) documented signatures of tide- and wave-reworking in the upper part of the Barakar Formation. Their study was confined in Barakar River section only. On the basis of tideand wave-led sedimentary structures, they primarily proposed an estuary depositional environment for the Barakar Formation, with predominance of two distinct depositional systems: (i) basal fluvial system without any effect of marine tide/wave, and (ii) upper tide-wave led fluvio-marine interactive system. However, detailed facies architecture from all outcrop sections and there analysis in the light of predominant tectono-sedimentary controls was warranted for reconstructing a more comprehensive depositional model of the Barakar Formation. This paper deals with detailed facies analysis from three outcrop sections - two major stream sections (Barakar River and Khudia River) and nearby open coal mine (Ramnagar-Chapatoria mine), and interprets them in the frame of transgressiveregressive cycles. The proposed depositional model is in conformity with that proposed by Bhattacharya et al. (2012), and is characterized by 3D facies architecture and the dynamics of its evolution through time, which makes this research unique and distinct from earlier reports.

In the present study, four major facies associations are identified within the studied Barakar Formation. Detailed account of different facies types in each facies association and their description and interpretation is presented in table 2 . The cross-stratified sandstone facies association (FA-B1) is predominant in the basal part of the succession. The sediments occur as laterally 

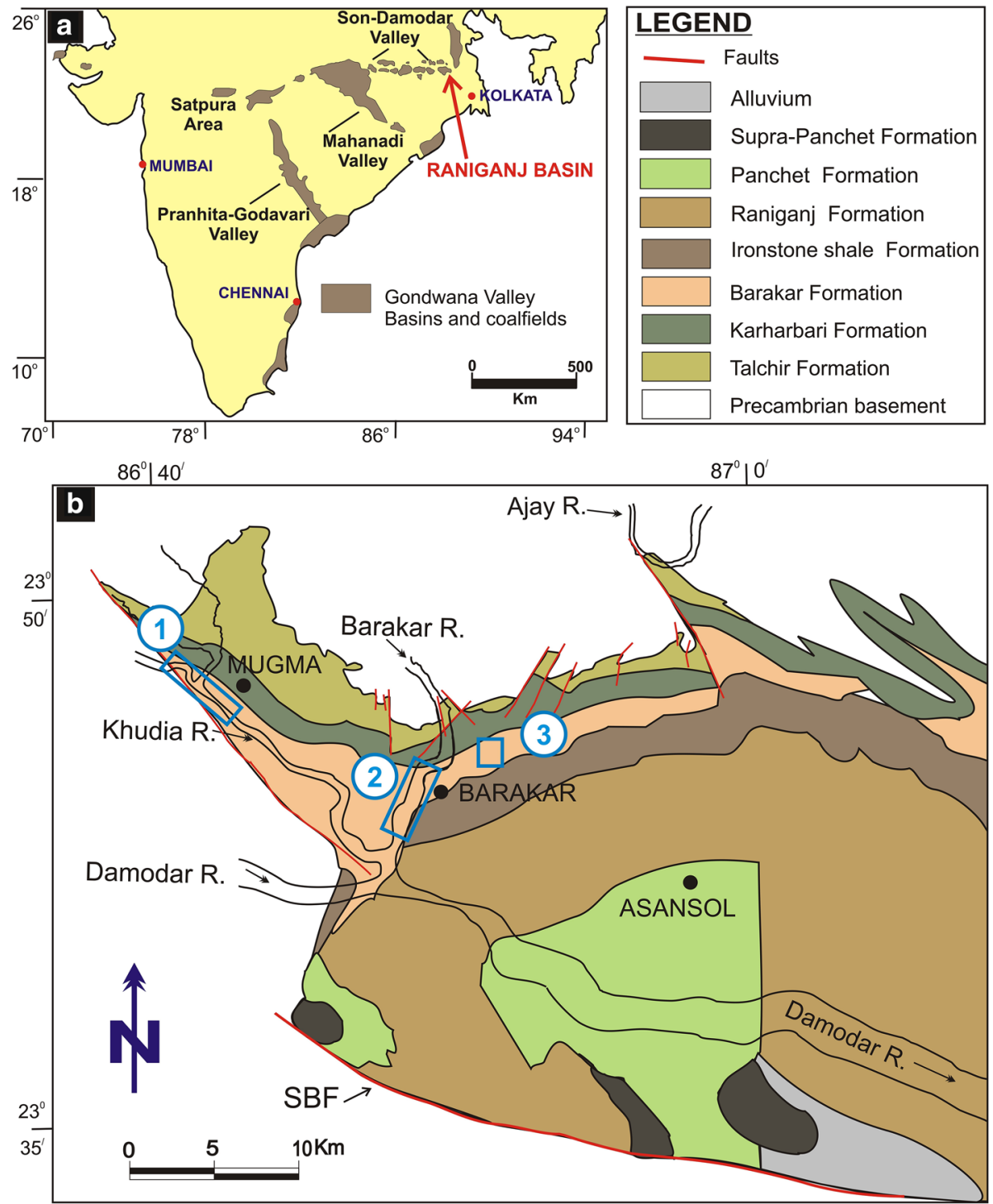

Figure 1. (a) Map of the part of peninsular India showing the distribution of the Gondwana basins. The location of the Raniganj Basin is labelled. (b) Detailed geological map of part of Raniganj Basin showing the occurrence of different Gondwana lithounits. The study areas are marked as 1: Khudia River, 2: Barakar River, and 3: Ramnagar-Chapatoria open pit area.

discontinuous, coarsening upward successions. This facies association consists of structureless to faintly laminated channel-fill sandstone (B1A) (figure 3a), trough cross-bedded sandstone (B1B) (figure 3b) that grade upward to plane-parallel laminated sandstone (B1C) (figure 3c), and lenticular conglomerate (B1D) (figure 3d). The small-scale coarsening-upward successions of dominantly cross-stratified sandstone with concave-up base indicate deposition from high-energy currents in channels. The lenticular conglomerate occurring at the bottom of trough cross-stratified sandstone beds demarcates channel lag deposits. Predominance of coarser clastics near the basal part (in FA-B1), followed upward by more mud-dominant channel-fill deposits (of FA-B2) signify changeover from initial braided river system to more mature meandering channel system.

The sandstone-mudstone-coal facies association (FA-B2) is dominated by (i) fining-upward laminated, carbonaceous, dark grey mudstone (figure 3e) with abundant leaf imprints and plant litters (B2A), and (ii) massive to faintly laminated sandstone (B2B). These finer sediments laterally and vertically grades to thick coal beds (B2C) (figure 3f) of humic bituminous type. The thickness and occurrence of the coal seams 
Table 1. Generalised lithostratigraphic succession of the Gondwana Supergroup in the Raniganj Basin (after Raja Rao 1987; Bhattacharya et al. 2016).

Unconformity.

Unconformity.

Triassic $\begin{cases}\text { Late } & \text { Supra-Panchet Formation } \\ \text { Early } & \text { Panchet Formation }\end{cases}$

..Mostly gradational contact, unconformity (local)/overlap at places.

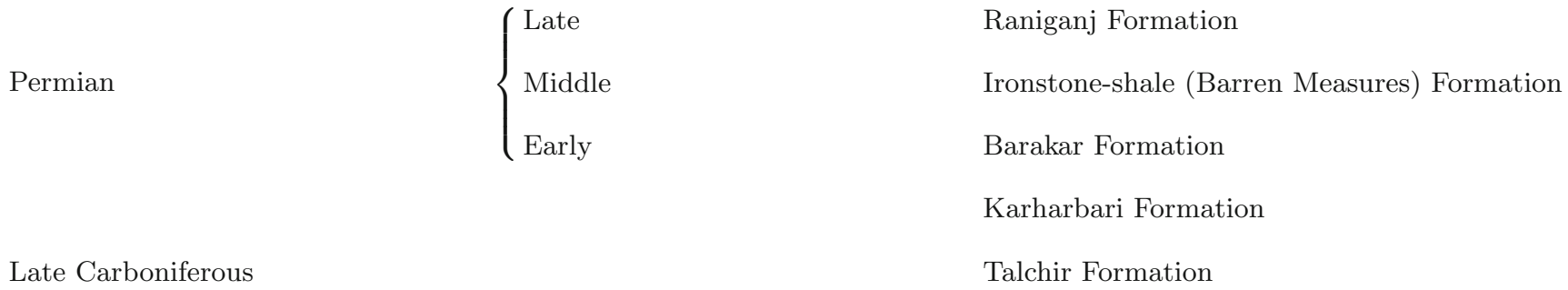

Unconformity (erosional)

Precambrian

Granite gneisses, schists with pegmatites and intrusives of metadolerite, dolerite and lamprophyre decreases to the top. The overall finer grain size of this association indicates that this is deposited in the floodplains of the channels. In the lower part of the succession FA-B2 alternates with FA-B1, indicating their deposition in more fluvial-dominated settings. Juxtaposition of this facies association with tidally-reworked sediments of FA-B3 in the middle part of the succession (figure 3f) indicates that the depositional condition shifted to inter-distributary bays, which were occasionally inundated by tidal flooding. Such bays surrounded by levees or marshes led to favourable conditions for the formation of peat/coal. Common association of the meandering fluvial sediments with the floodplain deposits (FA-B2) and tidally-reworked deposits (FA-B3) within overall progradational succession indicate deposition within a bay-head delta zone within the estuary system, produced by partial reworking of fluvial discharge by low energy tidal flooding at the river mouth. This facies association suggests deposition in more fluvial-influenced setting near to the tidal limit within the estuary system.

The sandstone-siltstone-mudstone facies association (FA-B3) occurs as extensive sheet and passes to wavy-hummocky laminated sandstone facies association (FA-B4). FA-B3 consists of gradationally based upward-fining successions showing frequent alternations of finer-grained sandstone-mudstone heterolithic sediments, viz., plane-parallel laminated heterolith (B3A) and wavy-/lenticularbedded heterolith (B3B), with coarser-grained cross-stratified sandstone (B3C). The coarser sediments are characterized by abundant tidal 


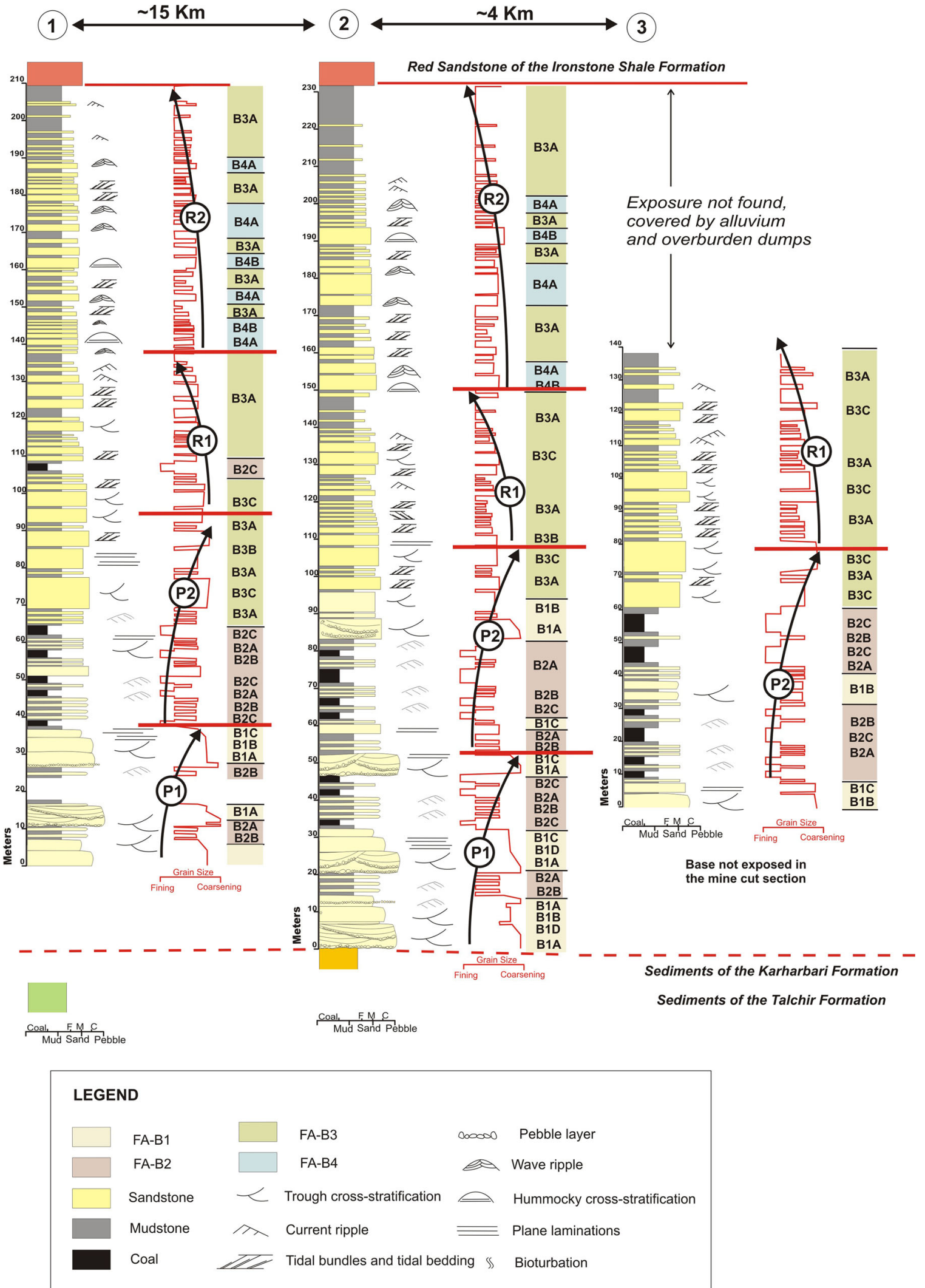

Figure 2. Detailed sedimentary logs of the Barakar Formation from the study areas: 1: Khudia River, 2: Barakar River, and 3: Ramnagar-Chapatoria open pit area, showing distribution of different sedimentary units in different facies associations, dominant primary sedimentary structures, and prominent coarsening-up progradational (P1, P2) and fining-up retrogradational (R1, R2) successions. 


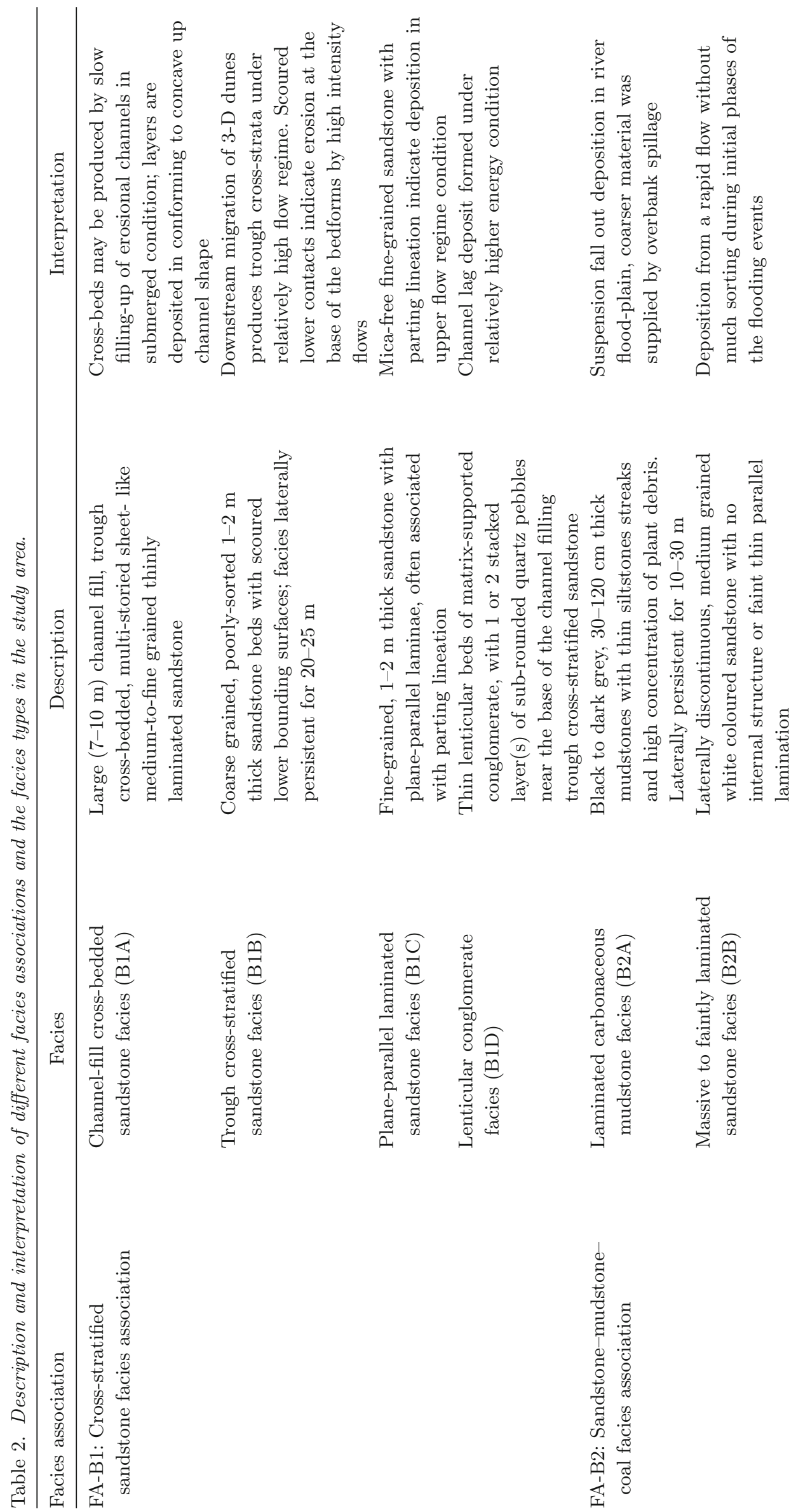




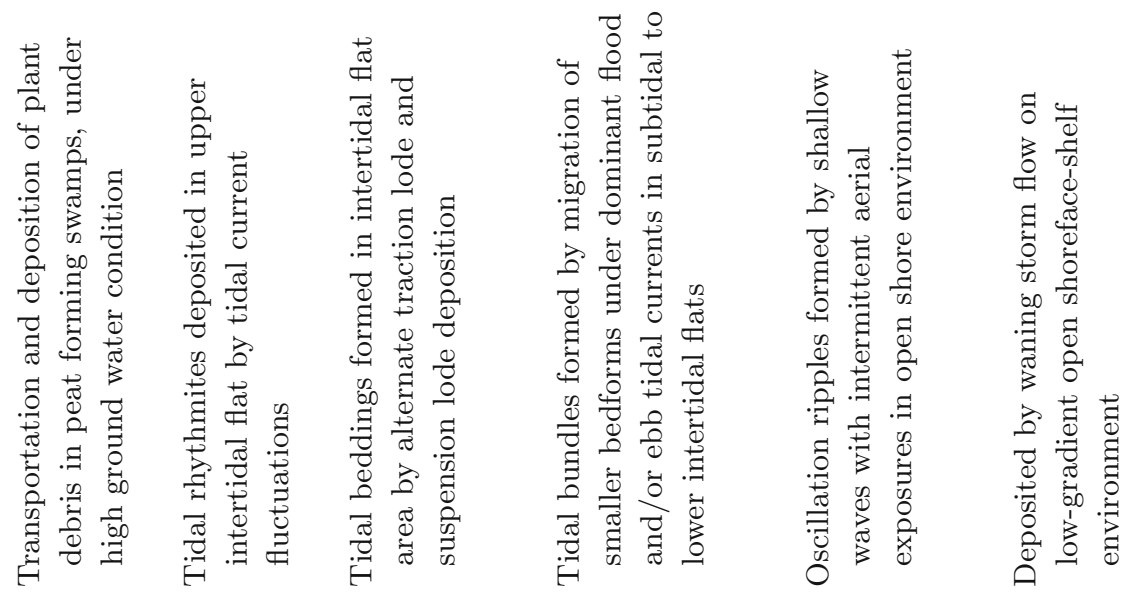
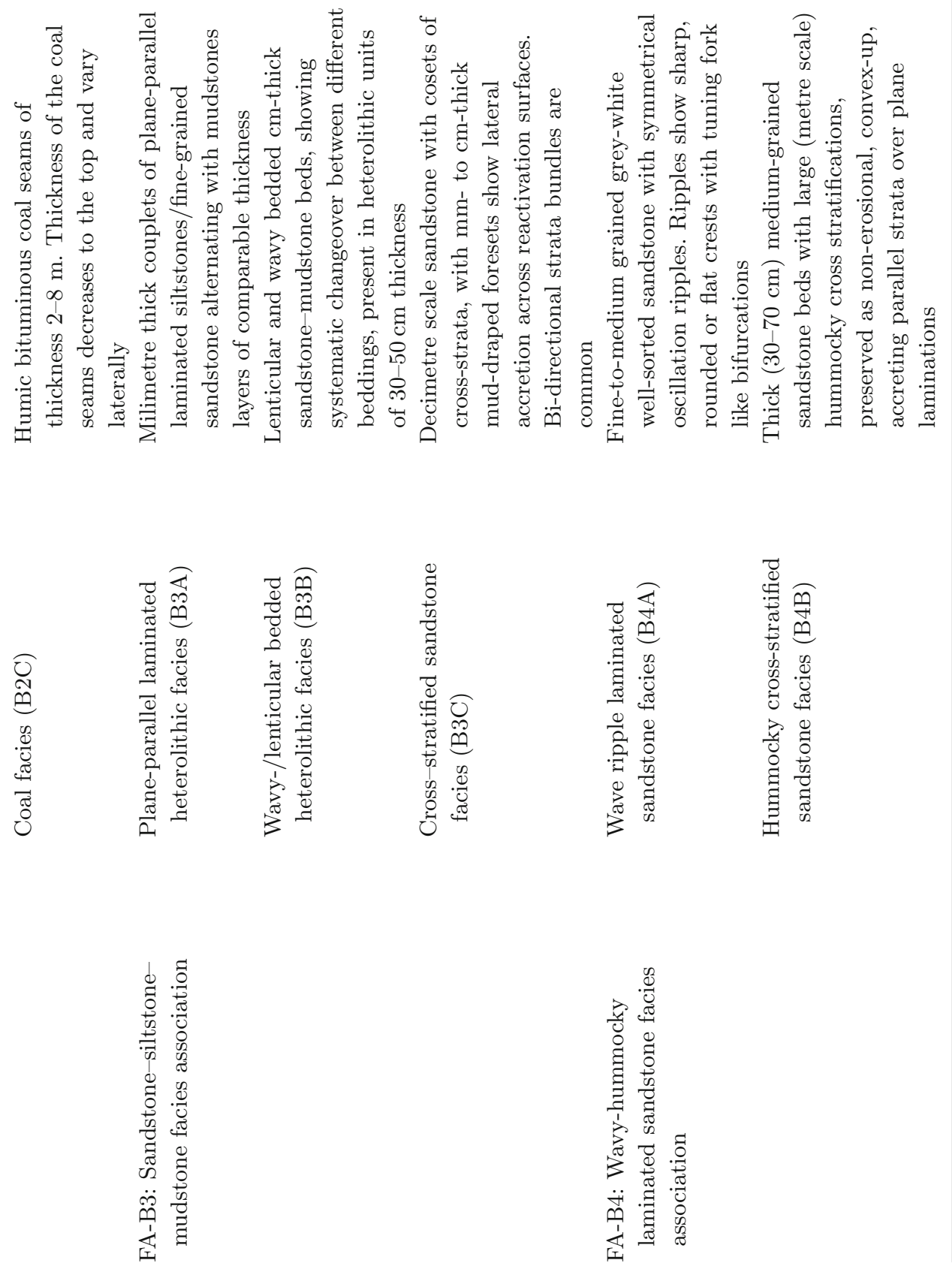

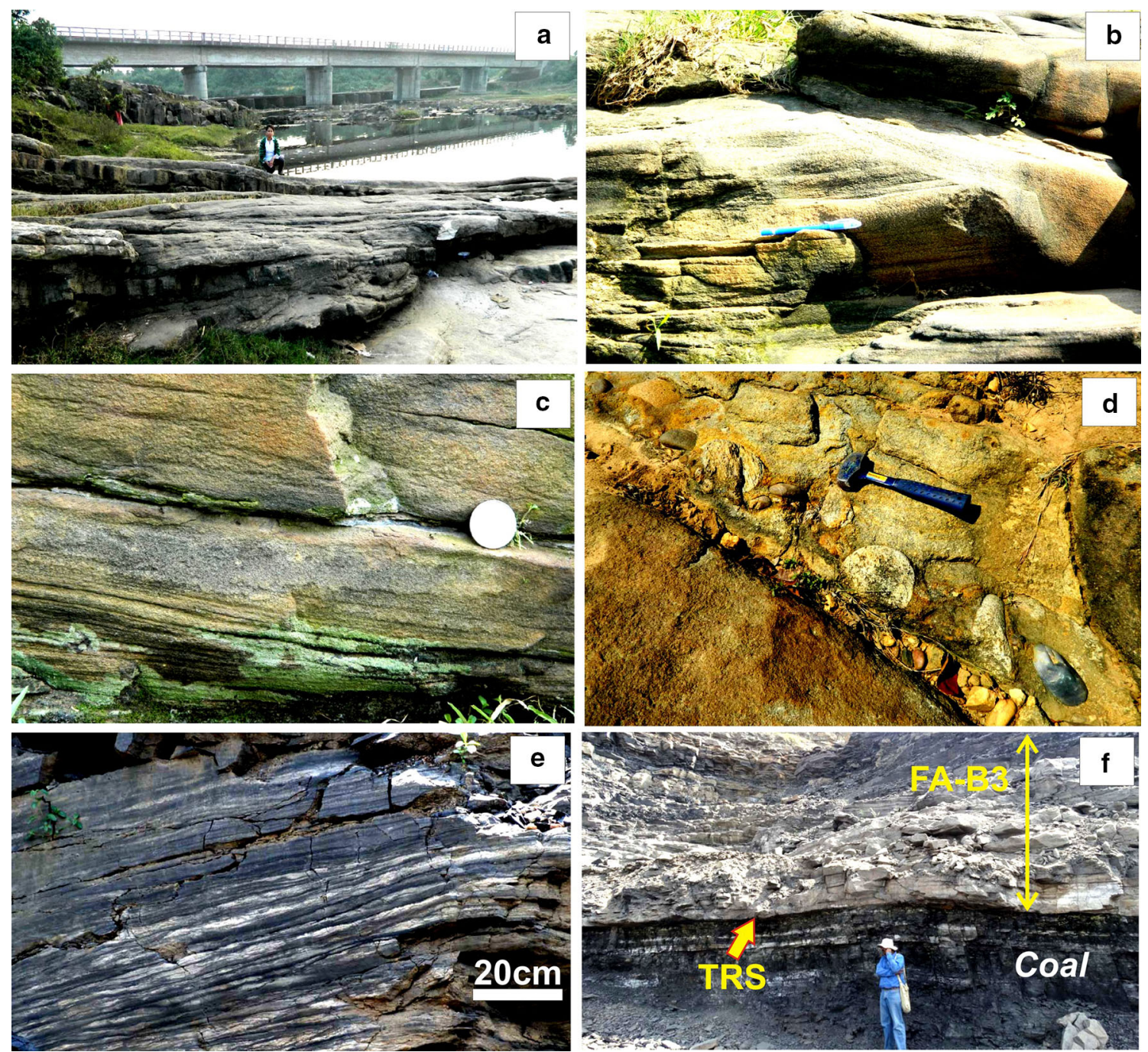

Figure 3. Field photographs of different facies types in facies associations FA-B1 and FA-B2. (a) Large channel-fill crossstratified sandstone facies (B1A). Person sitting in the photo is for scale. (b) Trough cross-stratified, coarse-grained sandstone facies (B1B). Length of the pen is $15 \mathrm{~cm}$. (c) Plane laminated sandstone facies (B1C). Diameter of the coin is $2.3 \mathrm{~cm}$. (d) Lenticular conglomerate facies (B1D), locally present at the base of trough cross-bedded sandstone. Length of the hammer is $30 \mathrm{~cm}$. (e) Laminated carbonaceous (dark grey) mudstone facies (B2A) with streaks of white sandstone (lenticular bedding), exposed in the wall of the Ramnagar open pit coal mine. (f) Thick coal seam overlain by succession of FA-B3 exposed in the Chapatoria open pit coal mine. Note the sharp and abrupt contact of the coal and the overlying sandstone of FA-B3, identified as tidal ravinement surface (TRS). Person in the photo is for scale.

bundles (figure 4a, b) showing signatures of lateral accretion of bundles with frequent reactivation surfaces formed under spring-neap-spring tidal fluctuations, sigmoidal bundles and bi-directional bundled strata sets (figure 4a). The finer fractions are characterized by abundant tidal rhythmites (B3A) (figure 4b) and tidal beddings (B3B) (figure 4c). Symmetrical wave ripples occur occasionally.

The wavy-/lenticular-bedded deposits, tidal bundles with reactivation surfaces, sigmoidal bundles and bi-directional cross-strata, indicate deposition under tidal currents with fluctuating current speed and flow direction. Coarser sediment fractions suggest deposition of tidal bars within the channels with less significant fluvial influence in the central basinal part of the estuary system (Dalrymple and Choi 2007). The finer heterolithic strata with high mud content indicate deposition in the tidal flats and distal tidal bars within the central estuary part.

The wavy-hummocky laminated sandstone facies association (FA-B4) consists of laterally continuous, wave ripple laminated sandstone (B4A) and hummocky cross-stratified sandstone (B4B) (figure $4 \mathrm{~d}$ ), indicating deposition in open marine 

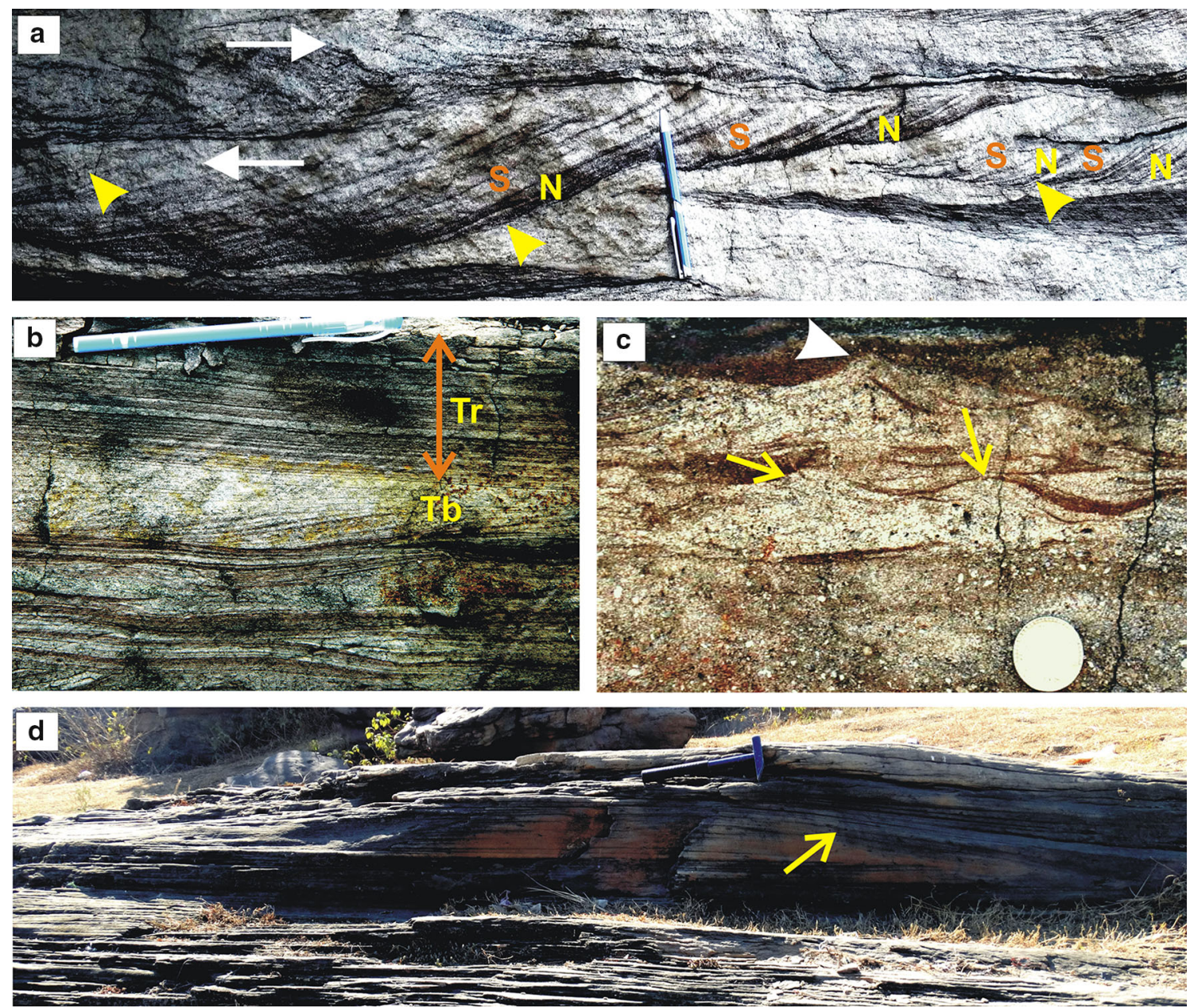

Figure 4. Field photographs of facies associations FA-B3 and FA-B4. (a) Coarse-grained sandstone (B3C), exposed in the Chapatoria open pit mine, showing abundant tidal bundles with reactivation surfaces (yellow arrow). Alternate sanddominated and mud-dominated thick-thin pairs of strata bundles signify spring $(\mathrm{S})$-neap (N)-spring (S) tidal fluctuations. Apparent bi-directionality of foresets is marked with oppositely oriented arrows (white). Length of the pen is $15 \mathrm{~cm}$. (b) Tidal rhythmites (Tr) in fine grained sandstone-mudstone heterolith (B3A) alternating with tidal bundles (Tb), exposed in the Ramnagar open pit mine. Length of the pen is $15 \mathrm{~cm}$. (c) Field photograph of B4A showing association of wave ripple (white small arrow), combined flow ripples (yellow long arrow) and partly preserved tidal beddings (wavy-bedding), exposed in the Khudia River section. Diameter of the coin is $2.3 \mathrm{~cm}$. (d) Large hummocky cross-stratification (arrow) within B4B, exposed on the bank of the Barakar River. Length of the hammer is $30 \mathrm{~cm}$.

coastal environment. Flat topped ripples, ripple bedforms with rounded crests and ladder back ripples bear signatures of intermittent exposure, suggesting development of a beach/tidal flat setting. However, their association with combined flow ripples and other tidalites (of FA-B3) (figure 4c) signify that the wave ripples actually formed on the tidal flats and beaches near the estuary mouth, where open marine wave reworking was possible. Within the estuary systems, with very low gradients and a muddy substrate, marine waves are dampened significantly (Coleman and Gagliano 1965) and allow preservation of abundant tide-generated structures.

\section{4. $\mathbf{T}-\mathbf{R}$ cycles in Barakar succession}

Vertical and spatial distribution of lithounits of the four facies associations have produced dominant progradational cycle in the lower part, and dominant retrogradational cycle in the upper part (see figure 2). Within the progradational succession, two major stacked progradational successions (P1 and P2) are identified, characterized by coarsening-up facies architecture. In the upper retrogradational part, two distinct fining-up successions (R1 and R2) are recognized (see figure 2).

The lowermost progradational succession (P1) is dominated by stacked channel-fill coarser clastics 
(FA-B1) with minor flood plain deposits (FA-B2), indicating deposition in braided channel systems. The bases of such successions are marked by sharp, erosional scoured surfaces, indicating successive channel incisions. The overlying progradational succession (P2) is distinctly different from P1. The lower part of $\mathrm{P} 2$ manifests predominance of meandering channel systems and associated flood plain deposits of FA-B2. Evidences of channel incisions are rare. Predominance of mud-rich floodplain deposits with thick coal seams manifest rising base level conditions, leading to (i) raising of river profile, (ii) more deposition in channels than incision, and (iii) slow rate of progradation associated with aggradation of sediments. Significant tidal reworking (FA-B3) near the upper part of $\mathrm{P} 2$ supplied more coarse particles into the system, forming bay head delta near the river mouth. The channels were flooded and produced aggradational and progradational sediment packages of mixed fluvial - tidal origin. Steady base level rise and associated changes in accommodation is responsible for such shift in depositional condition from lower to upper part of P2.

The upper part of the log is represented by two retrogradational fining-up successions, R1 and $\mathrm{R} 2$. Fining-up succession in $\mathrm{R} 1$ is dominated by signatures of tidal sedimentation (FA-B3), with minor records of fluvial inputs (FA-B2). Whereas, the fining-up succession in $\mathrm{R} 2$ is characterized by open marine wave-led sediments (FA-B4) with significant tidal influences (FA-B3). Stacked retrogradational successions manifest sustained onlap of the marine tide- and wave-led systems over the underlying progradational successions. Sharp erosional surfaces truncating fine-grained mudstone/shale, overlain by thick sandstone beds with prominent tidal bundles, commonly mark the shift from P2 to R1, and are identified as tidal ravinement surfaces. Similarly, a wave ravinement surface is commonly identified at the base of the wave rippled sandstone beds and the hummocky crossstratified sandstone beds at the base of the R2 succession, indicating further onlap of the coastal and open marine wave/storm systems. Thus, lateral correlation reveals vertical changes of five distinct conditions (i) scoured surfaces at the base of P1, indicating subaerial erosion by channel incision, (ii) a braided fluvial system (dominantly FA-B1) constituting the basal progradational succession (P1), (iii) a river-dominated, tide-influenced bay-head delta zone, with meandering channels (FA-B1) and flood plains (FA-B2) near the base, leading to predominant progradational succession (P2); (iv) a mixed energy, central basin zone, consisting of transitional fluvio-tidal channels, tidal flats, associated with tidal channels and bars (dominantly FA-B3, associated with FA-B2), leading to initial retrogradational (R1) succession; and (v) a wave-dominated coastal zone (FA-B4) with significant tidal influence (FA-B3), leading to final retrogradational (R2) succession (figures 2, 5). Such stacked T-R cycles signify a paleogeographic scenario consisting of a series of river valleys separated by interfluves that was inundated and flooded by coastal transgressions. As a result, a tidallyinfluenced estuarine setting developed adjacent to a wave-dominated coast (figure 5). As observed in many modern analogues, river flows, tidal currents and waves can interact or separately dominate different parts of the same estuary, leading to the development of a mixed energy depositional system.

\section{Sequence stratigraphic architecture}

In the sequence stratigraphic framework, the studied Barakar sedimentary succession shows one major base level fluctuation from initial falling and lowering to next rising. Within such cycle, three major systems tracts, viz., a falling stage systems tract (FSST), followed by a lowstand systems tract (LST) and a sustained transgressive systems tract (TST), are identified on the basis of the confining boundaries and associated sedimentary facies architecture (see figure 6).

\subsection{Bounding surfaces}

Three major and two minor bounding surfaces are identified within the studied Barakar succession, based on detailed field study, changes in vertically adjacent facies and correlation of the logs. These major surfaces are basal subaerial erosional surface (SES), maximum regressive surface (MRS) and maximum flooding zone (MFZ), and the minor surfaces are tide- and wave-ravinement surfaces (TRS/WRS).

The basal subaerial erosional surface (SES) is present at the base of the progradational succession $\mathrm{P} 1$ and is marked by persistent scoured and erosional surface (figure 6). Signatures of channel incisions are also common. This surface 


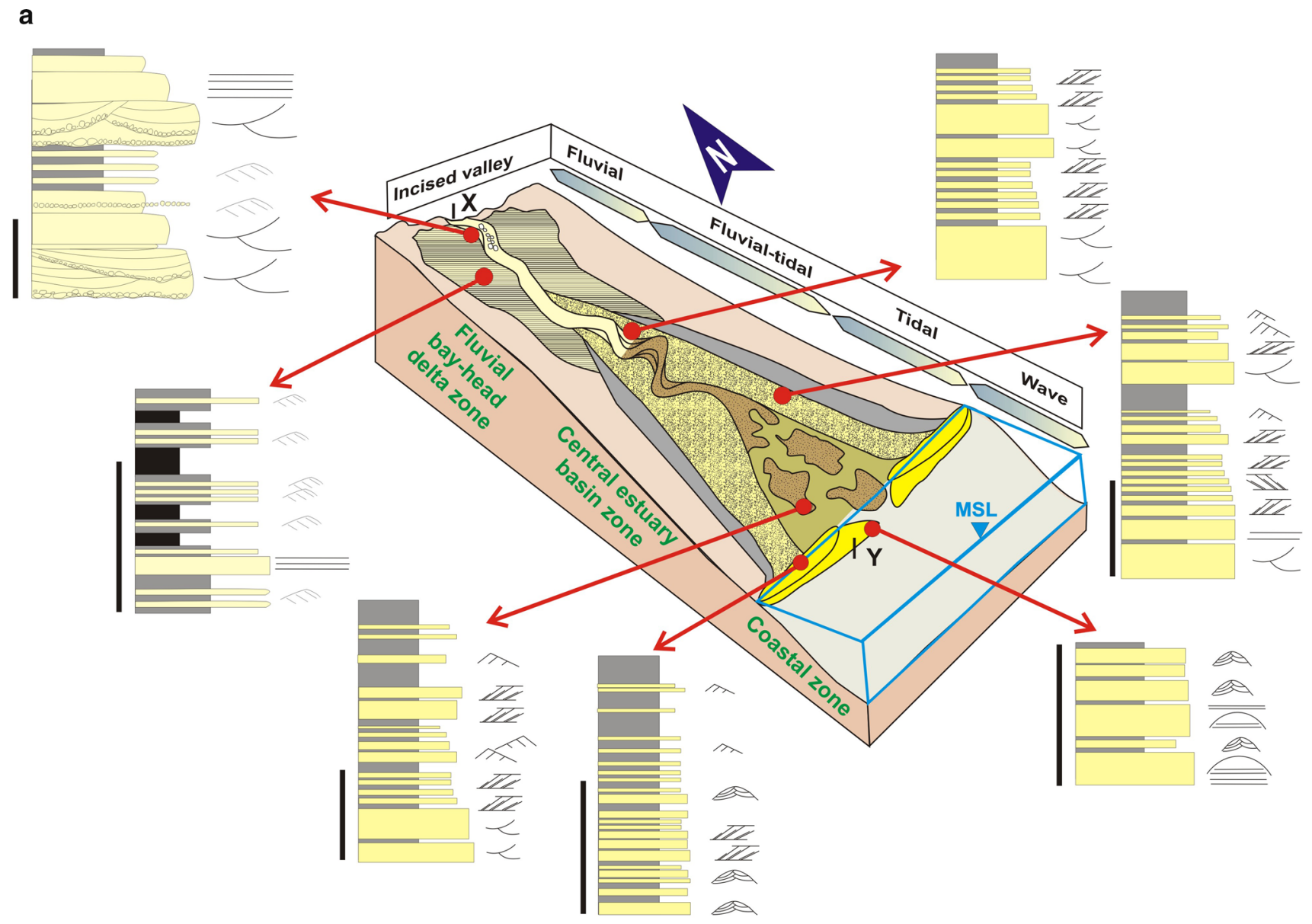

b
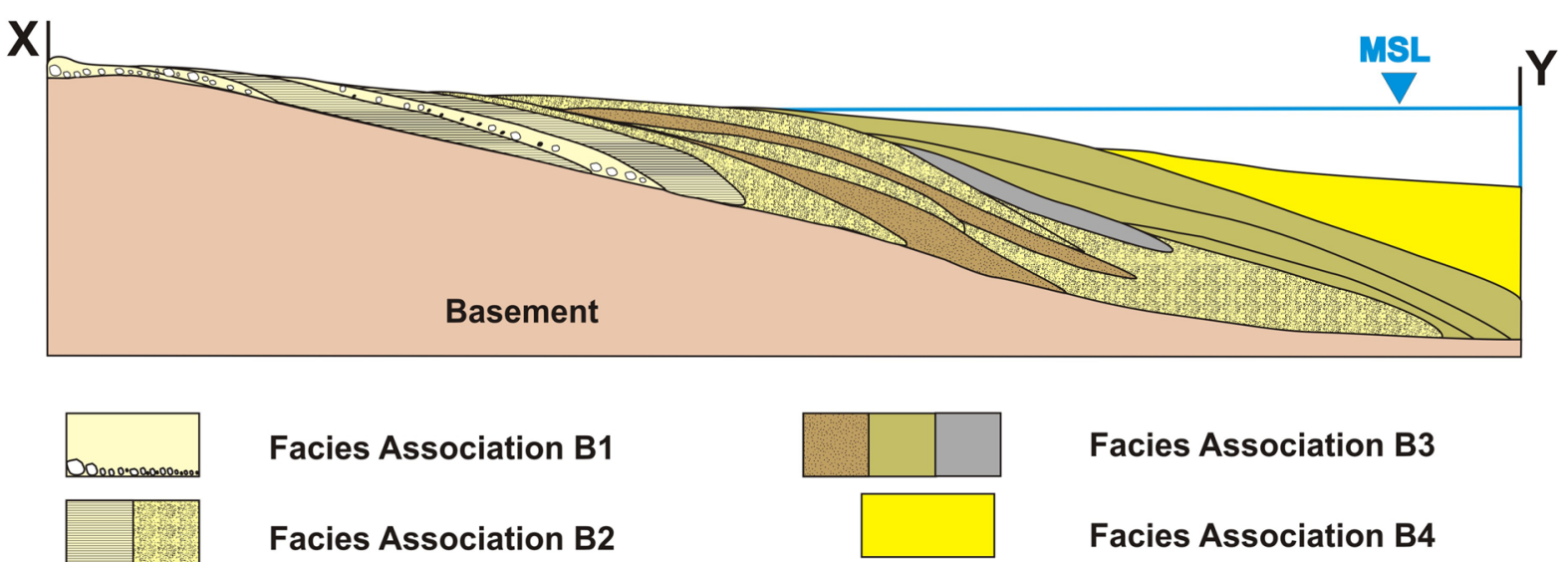

\section{Facies Association B3}

Facies Association B4

Figure 5. (a) Generalized fluvio-marine estuarine depositional model of Barakar sedimentary succession, Raniganj Basin, showing the distribution of different facies associations, depositional systems and facies models in each system. (b) Conceptualized occurrence and distribution of different facies associations in vertical section (along the line XY). Diagrams are not to scale.

marks sharp change in lithology, overlain by coarse-grained pebbly sandstone of the Barakar Formation and underlain by fine-grained sediments of the Talchir Formation/Karharbari Formation, which can be easily recognized in the field and in correlated logs (figures 2, 6). This surface marks the basal bounding surface of the lowstand systems tract (LST) in the studied section.

The maximum regressive surface (MRS) is identified in the correlated log sections through sharp change between progradational (P2) to retrogradational (R1) successions (figures 2, 6, 7). In field exposures, this surface is demarcated at the 


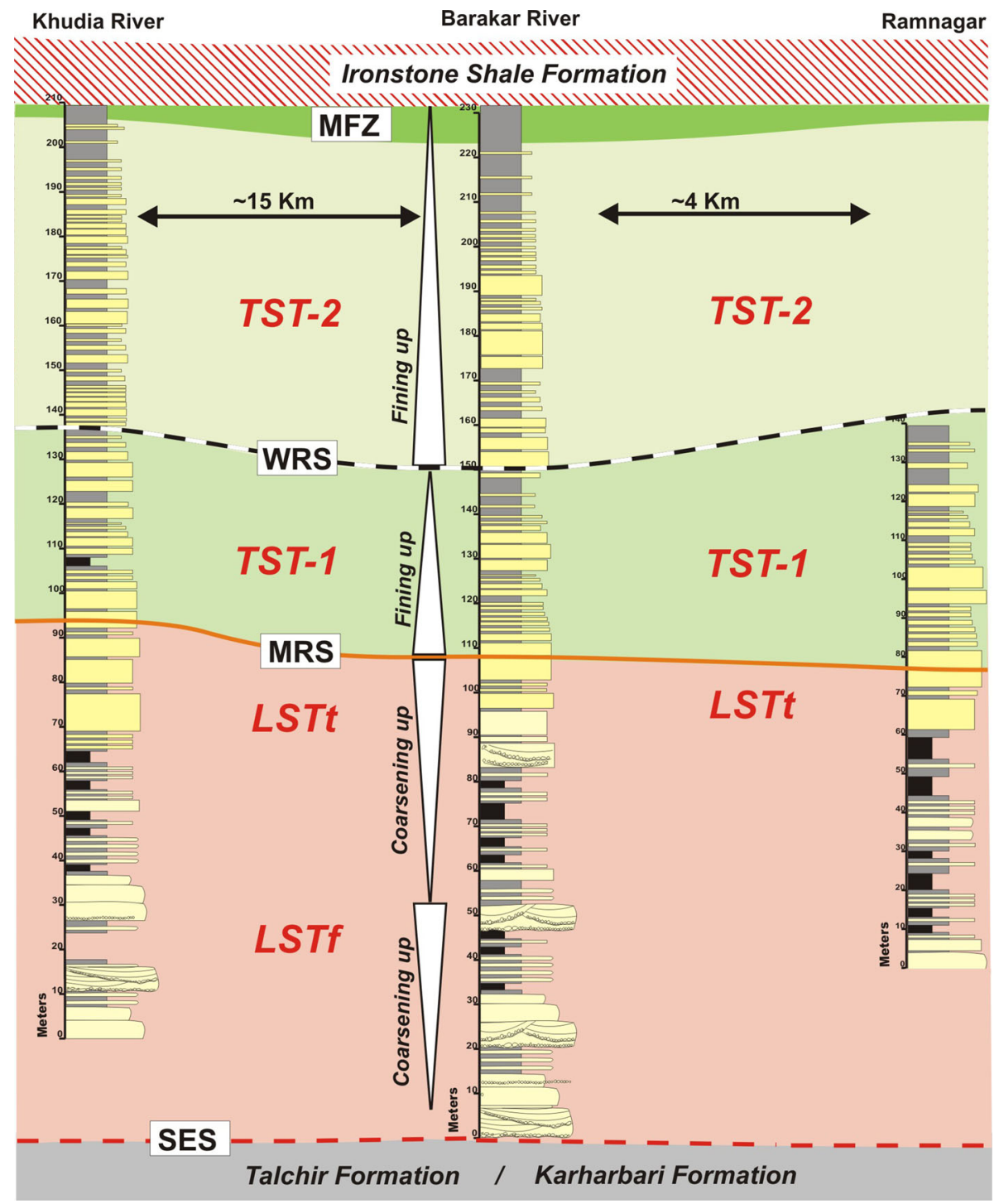

Figure 6. Sequence stratigraphic correlation of the logs of Barakar Formation. Letter symbols:- SES: subaerial erosional surface, MRS: maximum regressive surface, WRS: wave ravinement surface, MFZ: maximum flooding zone, LSTf: lowstand systems tract (fluvially-dominated), LSTt: lowstand systems tract (tidally-dominated), and TST: transgressive systems tract.

transition of coarsening-up succession to fining-up successions (figure 6). This surface marks the upper boundary of the LST and the lower boundary of the transgressive systems tract (TST).

The top of the TST is represented by thick carbonaceous shale, which grades upward to shalesandstone lithoassemblage of the overlying Ironstone shale (Barren Measures) Formation. Due to gradual change over from carbonaceous shale to shale-sandstone succession, we prefer to put a maximum flooding zone (not a single surface) in the upper part of the succession (figure 6), where fining-up succession changes to coarseningup. These shale units are laterally traceable for kilometres.
Apart from these major surfaces, other minor boundaries observed in the Barakar sedimentary succession are flat erosional surfaces (TRS and WRS), laterally continuous for $10-100 \mathrm{~m}$. The overlying sediment package is represented by estuarine, tidally-dominated deposits (tidal channels) (figures 2, 3f, 6) or coastal, wave-dominated deposits.

\subsection{The falling stage systems tract}

Fall in the relative sea level exposes the previously deposited sediments for erosion. It is marked by distinct erosional surfaces/subaerial unconformities and overlying siliciclastic sediments 


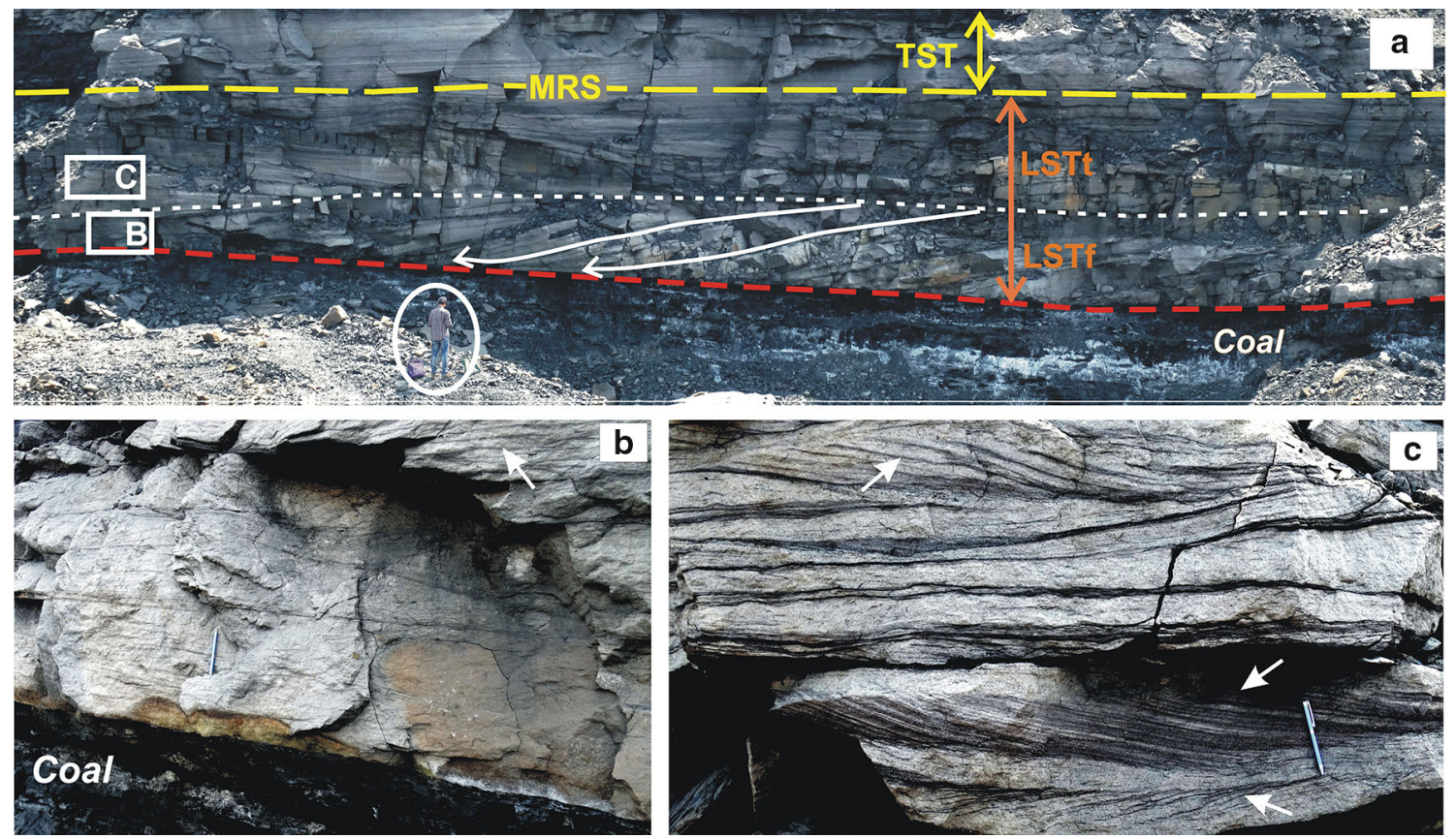

Figure 7. (a) Exposed vertical section in the Chapatoria open pit mine, showing fluvial-dominated LST (LSTf), followed up by tidally-dominated LST (LSTt) and tidally-dominated TST units. LSTf is characterized by successive progradational units, marked with white arrows, on a sharp downlapping surface (red dashed line). LSTt is characterized by tide-dominated aggradational units and is separated from overlying TST through maximum regressive surface (MRS). Areas marked under rectangles $\mathrm{B}$ and $\mathrm{C}$ are enlarged in (b) and (c), respectively. Person (encircled) standing in the photograph is for scale. (b) Enlarged view of the LSTf unit, showing fluvially-dominated cross-stratified sandstone, overlying coal units with sharp basal contact. Tidal bundles (arrow) are partly developed near the upper part. Length of the pen is $15 \mathrm{~cm}$. (c) Enlarged view of the LSTt unit showing tidally-dominated cross-stratified sandstones, with development of abundant tidal bundles (arrow). Bi-directional strata bundle sets are also observed near the lower part. Length of the pen is $15 \mathrm{~cm}$.

of continental origin. The base of the Barakar succession (P1), characterized by incised valley systems and sharp subaerial erosional surfaces (SES), demarcates a falling stage condition and is identified as the falling stage systems tract (FSST) (figures 6, 8). This surface marks the boundary between Barakar Formation and the underlying Talchir Formation/Karharbari Formation (figures 2, 6).

\subsection{The lowstand systems tract}

The early stages of relative sea level rise are marked as lowstand system tracts (LST), which are represented by initial prograding (P1) braided fluvial system (LSTf) and then, prograding and aggrading sequence (P2) of fluvial origin with significant tidal influences (LSTt) (figures 6, 7). The braided river deposits within LSTf in the lower part of the Barakar Formation record start of deposition in incised valleys in response to start of rise of the base level. The succession with LSTt records more matured fluvial system with significant tidal influences, accumulated during further sea level rise. This led to additional accommodation space, but the rate of sediment supply by the river overpaced the rate of sea level rise, resulting in a progradational and aggradational sequence identified as tidally-influenced lowstand systems tract (LST) (figures 6, 7, 8).

During the LST, the rate of increase in the accommodation space is less than the rate of sediment supply, which produces a seaward shift of the facies accumulation (forestepping sequence) (figures 6, 8). The maximum regressive surface (MRS) (figures 6, 7, 8) marks the change in stratal stacking patterns from maximum lowstand normal regression (progradational) to consequent transgression (retrogradational).

Continued sea level rise, accompanied by basinal subsidence caused by reactivation of basinmarginal faults, led to additional net accommodation space over the sediment supply. This allowed deposition of a fully estuarine, retrograding sediment package (of facies associations B3). A sharp 


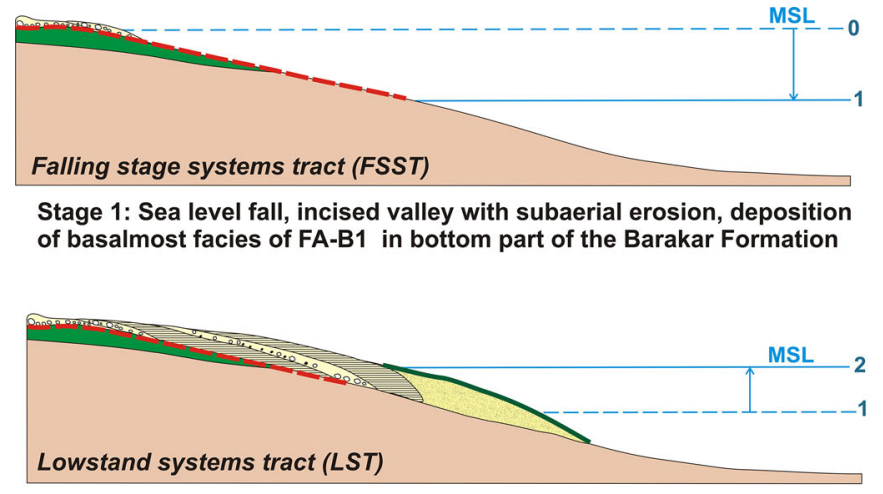

Stage 2: Sea level rise leading to accommodation space; flooding in incised valleys leading to prograding and aggrading sequences within fluvial bay head delta, deposition of FA-B1 and FA-B2 in lower part of the Barakar Formation, bounded by MRS on top.

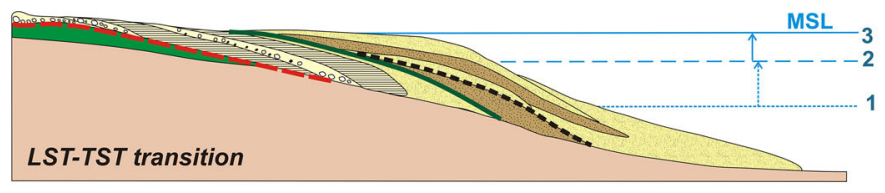

Stage 3: Continued sea level rise lead to more accommodation space; change from prograding - retrograding sequence in a fluvial-tidal mixed estuarine system; deposition of FA-B3 with FA-B2 in the middle part of the Barakar Formation; Transgressive event starts with distinct Tidal ravinement surface (TRS).

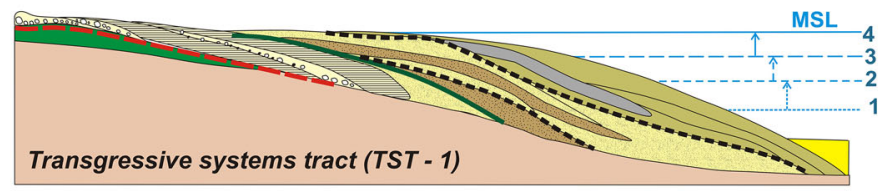

Stage 4: More accommodation space under transgressive condition lead to retrograding sequence, development of central estuary basin with tidal dominated sedimentation; deposition of FA-B3 with FA-B2 with multiple Tidal ravinement surfaces (TRS).

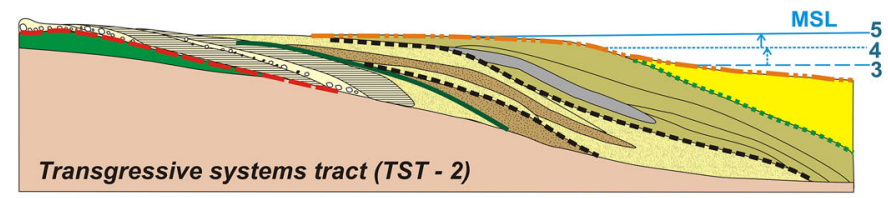

Stage 5: Sustained transgressive phase leading to retrogradation of open marine coastal facies (FA-B4), with development of distinct wave ravinement surface (WRS); Maximum flooding zone marks the termination of transgression at top of the Barakar Formation.

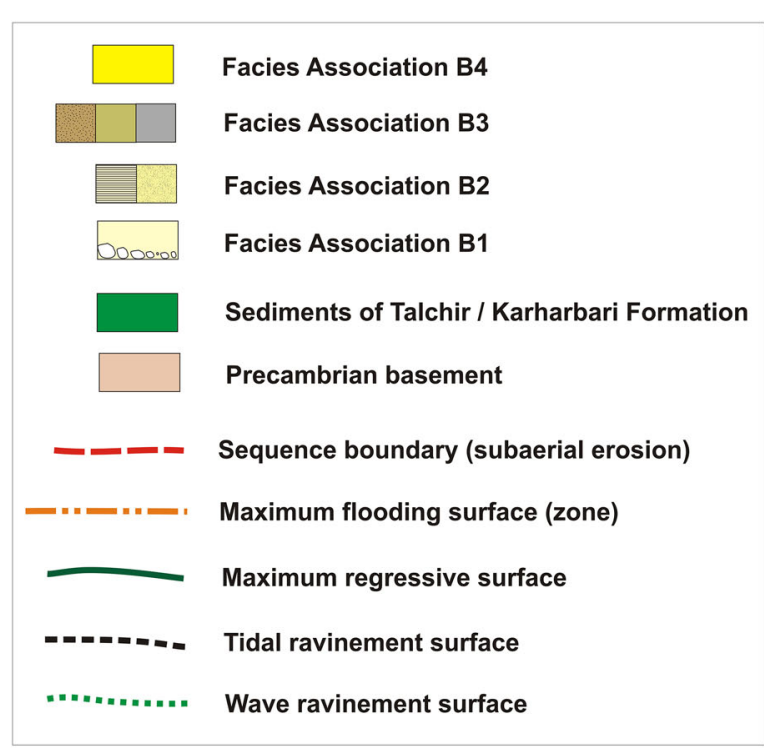

Figure 8. Schematic model showing stages of evolution (Stage-1 to Stage-5) of the Barakar sedimentary succession, Raniganj Basin, in the light of fluctuations in accommodation space and development of prominent sequence stratigraphic elements.

surface of initiation of retrogradation is identified locally and is interpreted as tidal ravinement surface (TRS) (figures 3f, 8). Incision of previous deposits during relative sea level lowstand episodes repeated several times, as the relative sea level lowstand phase was punctuated by a series of higher (4th/5th) order cycles as a result of the recurring erosion of previously deposited strata and ensuing infilling. The resulting 'compound fill' therefore records multiple cycles of incision and deposition in response to fluctuations in base level.

\subsection{The transgressive systems tract}

The onset of transgression is marked by the transgressive systems tract (TST) occurring above the lowstand systems tract (LST), separated by the MRS (figures 6, 7). During the transgression, the rate of increase in accommodation is more 
than the sedimentation rate. The first transgressive systems tract (TST-1) is indicated by the fining upward, predominant tidal facies present (in R1) with insignificant signature of fluvial deposition. TST-1 is typically a slowly backstepping (landward shift of facies) retrograding sequence (Thomas et al. 1987) (see figures 6, 7, 8). Locally tidal ravinement surface (TRS) is observed near the base of such sequences.

The subsequent stratigraphic interval is represented by another transgressive unit (TST-2), characterized by coastal sediments of estuary mouth system (succession under R2), which overlies the previous deposits through a wave ravinement surface (WRS). This was formed and accumulated during the prosecution of the next phase of transgression in the basin. This fining-up package was terminated by a maximum flooding zone at the top, demarcated by a thick carbonaceous shale unit (figure 6). In this part of the succession, at least three vertically stacked higher frequency cycles are identified, bounded by sharp flooding surfaces marked by concentrations of finer clastics (carbonaceous shale). These flooding surfaces bound single parasequences, each recording transgressive/regressive episodes of sedimentation in the wave-influenced coastal settings. Transgression may have occurred as a long lasting relative sea level rise paused by minor periods of sea level still-stands of shorter duration. During these still stands, the sediment accumulation rate overpaced the rate of formation of accommodation space, generating phases of normal regressions and resulting in small-scale shoaling upward parasequences.

The limit of the transgression is reached during the period when the rate of accommodation generation no longer outpaces the sedimentation rate at the shoreline. The thickest and most laterally extensive carbonaceous shales typically occur during this phase of the base-level cycle (Bohacs and Suter 1997). These widespread marine carbonaceous shales commonly mark the maximum flooding zone (MFZ) near the top part of the succession. During rapid transgressive phases, sediment supply is relatively low but increases during the ensuing relative sea level still-stands, producing normal regressive strata and progradation of nearshore facies. Such architecture, which is common in transgressive parasequence sets, as described in many coastal wave-dominated successions, suggest that the transgression was punctuated by temporary arrests of the relative sea level during which the overpass of the sediment accumulation rate on the accommodation space generated normal regressions.

\section{Discussion on paleogeography}

The Tethyan strandline experienced a major regression during the post-Talchir early Permian time in peninsular India (Veevers and Tewari 1995; Bhattacharya and Bhattacharya 2015). This regressive event led to exclusive continental fluvial depositional settings (viz., the Karharbari Formation and the lower part of the Barakar Formation) over the basal glaciomarine Talchir sedimentary successions (Bhattacharya and Bhattacharya 2015). Bhattacharya et al. (2012, 2016) documented evidences of tidal and storm intercalations within such continental fluvial channels (in the Raniganj Basin), which signifies that an open sea was close to the peninsular Gondwanaland during the Barakar sedimentation. The present paper provides significant evidences to establish the nature of marine incursions and resultant paleogeographic scenario during the Barakar sedimentation in eastern peninsular India.

Analysis of the Barakar sedimentary succession in the light of transgressive-regressive cycles depict two major environmental shifts, viz., (i) a braided to meandering fluvial system partly affected by tidal flooding leading to bay-head delta, characterizing the lower part of the succession, and (ii) a retrograding tide-wave influenced marine transgressive central to outer estuarine system, constituting the upper part of the succession. Signatures of drastic fall in base level, as evident from incised valleys within the falling stage system tract (FSST) at the base of the Barakar succession, is attributed to significant climatic amelioration accompanied by post-Talchir exhumation of the basin in response to post-glacial isostatic rebounce (Bhattacharya et al. 2005; Mukhopadhyay et al. 2010; Bhattacharya and Bhattacharya 2015). Differential vertical movement of basinal blocks within the crust led to reactivation of basin marginal faults in the riftogenic Raniganj Gondwana basin, which reciprocated subsidence of the basinal part allowing incursion of marine water within the basin (Bhattacharya et al. 2016). As a result, the estuarine deposits in the middle part of the succession represent phases of sustained sea level rise and its intercalation with the fluvial system (the LST). This sequence comprises tidal channels, tidal point 
bars, coal-bearing marshes and tidally inundated floodplains. This was followed by sustained phases of TSTs, when estuary mouth deposits and open marine coastal deposits onlapped the underlying LST sediment package. Bhattacharya et al. (2016) correlated the transgressive events with creation of net accommodation space in response to sea level rise and further basinal subsidence due to fault reactivation (through report of seismites). Thus, significant shift in the depositional conditions from fluvial-dominated to a transgressive tide-wave influenced estuarine system attests to significant tectono-sedimentary changes that led to prolonged events of marine transgressions in the Raniganj Basin during the Early Permian time.

\section{Conclusions}

Detailed sedimentological study of the Permian Barakar succession in the Raniganj Basin reveals:

- Twelve facies types distributed in four facies associations, viz., (a) basal braided fluvial channels, (b) meandering fluvial channels leading to bay head delta system, (c) central estuary basin system with fluvial-tidal interactions and (d) an estuary mouth coastal system with wavetide interactions.

- Progradational to retrogradational facies successions from bottom to top reveal systematic change in base level and net accommodation.

- Complete Barakar succession shows two distinct transgressive-regressive ( $\mathrm{T}-\mathrm{R})$ sequences, recording one dominant base level fluctuation from falling condition to the next rise.

- Formation of a falling stage systems tract (FSST) and fluvial-influenced lowstand systems tract (LSTf) near the lower part of the succession indicates lowering of base level with predominant fluvial sedimentation.

- Sustained marine influences under rising base level led to tide-influenced bay-head delta, comprising the next part of progradational to aggradational lowstand systems tract (the LSTt), attesting the start of marine encroachment into the fluvial system.

- Further onlapping of marine tide-wave influenced depositional systems produced a tideinfluenced early transgressive to wave-influenced late transgressive systems tract (TST-1 and TST-2), leading to significant landward shift of themarine depositional systems under a condition of rising base level and net accommodation creation.

- Such fluctuations in base level is attributed to crustal subsidence and syn-depositional reactivation of basin-marginal faults in response to post-glacial isostatic adjustments in the Permian Gondwana rift basins in peninsular India, particularly in the Raniganj Basin.

\section{Acknowledgements}

Authors are grateful to the Mine Authorities of Ramnagar-Chapatoria open pit mines for necessary permissions to visit the mines. B Bhattacharya received financial support from Department of Science and Technology (DST)-SERB in the form of FAST TRACK Research Project (No. SR/FTP/ES-170/2010) for this work. All the authors acknowledge their respective departments for the infrastructural help. Authors are also thankful to both the reviewers for constructive suggestions, which enhanced the clarity of the paper.

\section{References}

Bhattacharya B, Bandyopadhyay S, Mahapatra S and Banerjee S 2012 Record of tide wave influence on coal bearing Permian Barakar Formation, Raniganj Basin, India; Sedim. Geol. 267-268 25-35.

Bhattacharya B, Bhattacharjee J, Banerjee S, Bandyopadhyay S and Das R 2016 Seismites in Permian Barakar Formation, Raniganj Basin, India: Implications on Lower Gondwana basin evolution; Arab. J. Geosci. 9 1-13.

Bhattacharya H N and Bhattacharya B 2015 Lithofacies architecture and palaeogeography of the Late Palaeozoic glaciomarine Talchir Formation, Raniganj Basin, India; J. Palaeogeogr. 4 269-283.

Bhattacharya H N, Chakraborty A and Bhattacharya B 2005 Significance of transition between Talchir Formation and Karharbari Formation in lower Gondwana Basin evolution - a study in west Bokaro Coal Basin, Jharkhand, India; J. Earth Syst. Sci. 114 275-286.

Bohacs K and Suter J 1997 Sequence stratigraphic distribution of coaly rocks: Fundamental controls and paralic examples; AAPG Bull. 81(10) 1612-1639.

Casshyap S M 1970 Sedimentary cycles and environment of deposition of the Barakar Coal measures of Gondwana, India; J. Sedim. Petrol. 40 1302-1317.

Casshyap S M 1973 Palaeocurrent and palaeogeographic reconstruction in the Barakar (Lr. Gondwana) sandstones of peninsular India; Sedim. Geol. 9 283-303.

Casshyap S M 1979 Pattern of sedimentation in Gondwana Basins; Proc. IVth Int. Gond. Symp. 2 525-551.

Casshyap S M and Qidwai H A 1971 Palaeocurrent analysis of Lower Gondwana sedimentary rocks, Pench Valley Coalfield, Madhya Pradesh (India); Sedim. Geol. 5 135145. 
Casshyap S M and Tewari R C 1988 Depositional models and tectonic evolution of Gondwana basins of peninsular India; The Palaeobotanist 36 59-66.

Casshyap S M and Tewari R C 1991 Depositional model and tectonic evolution of Gondwana basins; In: Geol. Soc. India Memoir (eds) Venkatachala B S and Maheshwari H K; Indian Gondwana 21 195-206.

Chakraborty C, Ghosh S K and Chakraborty T 2003 Depositional record of tidal-flat sedimentation in the Permian Coal measures of central India: Barakar Formation, Mohpani Coalfield, Satpura Gondwana Basin; Gondwana Res. 6(4) 817-827.

Coleman J M and Gagliano S M 1965 Sedimentary structures: Mississippi River deltaic plain; SEPM Spec. Publ. 12 133-148.

Dalrymple R W and Choi K 2007 Morphologic and facies trends through the fluvial-marine transition in tidedominated depositional systems: A schematic framework for environmental and sequence-stratigraphic interpretation; Earth Sci. Rev. 81(3) 135-174.

Ghosh S K, Chakraborty C and Chakraborty T 2004 Combined tide and wave influence on sedimentation of Lower Gondwana coal measures of central India: Barakar Formation (Permian), Satpura Basin; J. Geol. Soc. 161(1) $117-131$

Corresponding editor: PARTha Pratim Chakraborty
Gupta A 1999 Early Permian palaeoenvironment in Damodar Valley Coalfields, India: An overview; Gondwana Res. 2 149-165.

Maiti R P, Chakraborty V, Laskar A, Dutta Roy S and Dutt A B 1990 Analysis of Lower Gondwana coal basins of peninsular India; Rec. Geol. Surv. India 2 234239.

Mukhopadhyay G, Mukhopadhyay S K, Roychowdhury M and Parui P K 2010 Stratigraphic correlation between different Gondwana basins of India; J. Geol. Soc. India 76(3) 251-266.

Mukhopadhyay S K 1996 Trace fossils as palaeoenviron mental and sedimentological indices of coal bearing Gondwana sequence; Proc. Vol. IXth Int. Gond. Symp. 1 505-528.

Raja Rao C S 1987 Coalfields of India; Bull. Ser. A. Geol. Surv. India 45(4) 1-335.

Thomas R G, Smith D G, Wood J M, Visser J, CalverleyRange E A and Koster E H 1987 Inclined heterolithic stratification - terminology, description, interpretation and significance; Sedim. Geol. 53 123-179.

Veevers J J and Tewari R C 1995 Gondwana master basin of Peninsular India - between Tethys and the interior of the Gondwanaland - Province of Pangea; Geol. Soc. Amer. Memoir 187 1-73. 